Egypt. Acad. J. Biolog. Sci., 13(2):313-322 (2020)

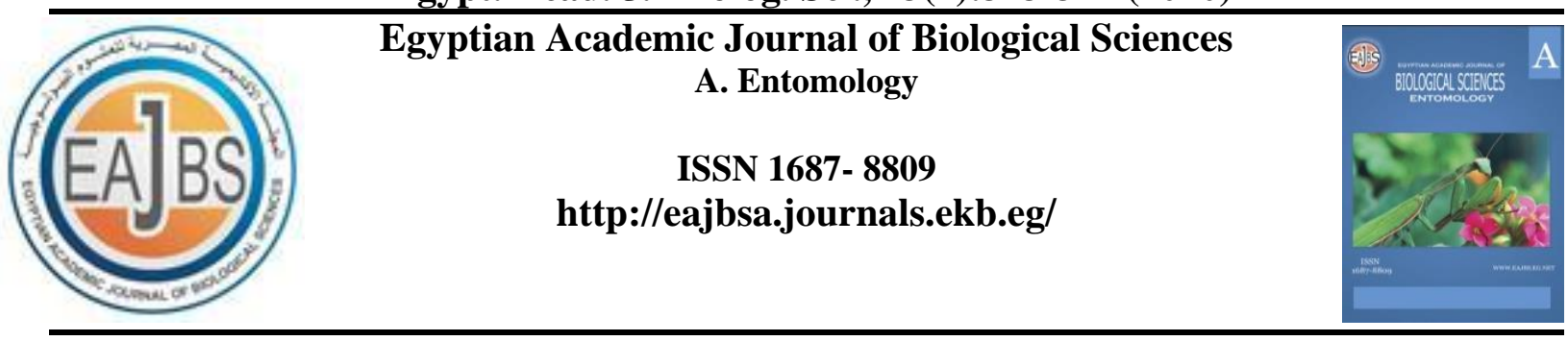

\title{
Population Fluctuation of Some Piercing-Sucking Pests and Their Associated Predator on Broad Bean Plants in Ismailia Governorate and Yield Loss for Aphid infestation
}

\author{
Abdelhalim, E. Khalil \\ Entomologist, Piercing \& Sucking Insects Res. Dept. Plant Protection Research Institute, \\ ARC, Dokki, Giza, Egypt. \\ Email: abdelhalem.khalii2016@gmail.com
}

\begin{abstract}
ARTICLE INFO Article History

Received:3/5/2020

Accepted: 29/6/2020

\section{Keywords:}

Aphids, population, Vicia faba, natural enemies, weather factor

\section{ABSTRACT}

Faba bean is an important position between leguminous food crops in Egypt. A piercing-sucking pest associated with broad bean plants causes serious damage, directly by sucking plant juices or indirectly as the aphid insects are vectors to plant diseases. A field experiment was conducted at Wadi Elmalak, Ismailia Governorate, Egypt in winter growing seasons 2018/2019 and 2019/2020. To evaluate the population fluctuation of some piercing-sucking pests and the common natural enemies and relation to weather factors on broad bean plants. Results indicated that the important piercing-sucking pests, pea aphid, Acyrthosiphon pisum (Harris) were the most dominant, followed by Aphis craccivora Koch, while green peach aphid, Myzus persicae (Sulzer), Thrips tabaci Lind. and Jassid, Empoasca discipiens Poali were found in low densities throughout the two seasons. The eleven spotted lady beetle, Coccinella undecimpunctata L., green lacewing, Chrysoperla carnea (Stephens), and seven-spotted lady beetle, Coccinella septempunctata L. are the most important predators which associated with the sucking insect pests on faba bean. The population fluctuation of piercing-sucking pests and associated predators were higher in the first season than in the second season. The pea aphid, A. pisum started with attacks broad bean in the second week of November and reached it has two peaks early January and in mid-May in the two successive years. The relationship between both of the population of piercing-sucking pests and associated predators and weather factors were studied. The loss in seed yield in the two successive seasons was evaluated all together being (330.0 kg. /fed). The avoidable losses in seeds yield were $(19.18 \%$ per fed.) during two seasons.
\end{abstract}

\section{INTRODUCTION}

Broad bean has an important leguminous food crop in Egypt. Many insect species associated with broad bean plants cause serious damage, directly by sucking plant juices or indirectly as the aphid insects are vectors to plant diseases Allam, 2009.

Bean crops are subjected to attacks by sucking pests, especially aphids, jassids, and thrips. Which causes serious damage, either directly by sucking plant juices or indirectly as vectors of virus diseases (Abdel-Alim, 1994; Hannou, 1995; Mahmoud et al., 2017; El- 
Sarand et al., 2019 and Khodeir et al., 2020). Many researchers studied that the effect of aphid on broad bean plants all over the country causing considerable yield losses due to direct feeding by sucking plant sap or to the indirect transmission of virus diseases (ElDefrawi and Mokhtar, 2007; Khattab et al., 2014; Mousa and Metwally, 2014). The natural enemies and climatic conditions are of the most important factors affecting the population dynamics of insect pests (Bylund, 1999 and Nuessly et al., 2004).

Most farmers in the different districts of Egypt have become familiar with a range of insecticides that they can use to increase their yields and profits. Three sprays at 15-20-day intervals are recommended for the control of this pest in the different regions of Egypt. (ElDefrawi and El-Harty, 2009). Hazard uses insecticides could kill beneficial insects such as the natural enemies and bees which pollinate many of our crops (El-Heneidy et al., 1991).

The study aimed to study the incidence and population fluctuation of the most common piercing-sucking pests and predators associated with broad bean plantation and whether factors in the Ismailia governorate during two seasons. The study also extended to investigate the effect of infestation with aphids on a yield of broad bean.

\section{MATERIALS AND METHODS}

Two field experimental designs were conducted at Wadi Elmalak, Ismailia Governorate, Egypt in winter growing seasons 2018/2019 and 2019/2020. The first study the population density of some piercing sucking pests and the common natural enemies and relation to weather factors on broad bean plants and the second study to determine the yield loss due to broad bean aphid infestation.

An area of half feddan was divided into two equal areas of experimental plots. Each plot was $6 \times 7 \mathrm{~m}^{2}$ (1/100 fed.), in a completely randomized block design with 4 replicates. Seeds were sown with broad bean, (Vicia faba L.) variety (Giza 716) on November $21^{\text {st }}$ \& $20^{\text {th }}$ during 2019 and 2020. The seeds were sown in the hills ( 2 seeds /hill in double rows) at a plant density of 24 plants $/ \mathrm{m}^{2}$ (=100800 plants/fed.). All normal regular agricultural practices were done in due time adopting the recommended packages and they were the same in all treatments. One of the two areas was sprayed occasionally at 2-week intervals starting on the infestation build-up with a selective carbamate insecticide (Aphox $50 \%$ DG), at the rate of $50 \mathrm{~g} / 100$ liter to keep the plants aphid-free (full protection). The other area was not sprayed with any insecticide to allow for natural infestation.

Populations of aphid, jassid and associated predators were recorded weekly from the third week of sowing until the end of the season. Samples of 40 leaflets faba bean plants were randomly selected from 10 plants were counted using the aid of $8 \mathrm{X}$ lens, early in the morning in the field. While for the sampling of thrips the method used was the shaking it consisted of the shaking of ten plants over a white tissue for each plot, using a small brush, the thrips were collected into $70 \%$ alcohol.

Data of meteorological, the daily mean of minimum, maximum temperature, and daily mean relative humidity were obtained from the meteorological records of Central Laboratory for Agricultural Climate, A.R.C. at Giza. The daily records of these factors were recalculated to get the daily averages within one week of the sampling date.

\section{Loss in Yield:}

The plots were harvested between 5-10 May in the two seasons. The final harvested seed yield was calculated from a net area of the $25 \mathrm{~m}^{2} /$ plot. The measure of damages caused directly by aphid infestation can be estimated based on seed yield obtained $\left(\mathrm{kg} . / 100 \mathrm{~m}^{2}\right)$ in treating plots naturally infested with aphids, compared to non-infested healthy plants in sprayed plots (El-Defrawi and Shalaby, 2002; El-Defrawi and El-Harty, 2009). 
Evaluate the loss in yield due to aphid infestation as follows:

Percent reduction in seed yield $=\mathrm{C}-\mathrm{T} / \mathrm{C} * 100$.

\section{Statistical Analysis:}

The statistical analysis using Simple correlation was used to correlate between weather factors and average weekly number of insects and natural predators, and analysis of variance (T-test) was adopted and the L.S.D values were used to determine the significance between means of yield seeds of protected and unprotected area (SAS Institute, 2003).

\section{RESULTS AND DISCUSSION}

A field experiment was conducted at Wadi Elmalak, Ismailia Governorate, Egypt in winter growing seasons 2018/2019 and 2019/2020. Results indicated that the important piercing-sucking pests, pea aphid, Acyrthosiphon pisum (Harris) were the most dominant, followed by Aphis craccivora Koch, while green peach aphid, Myzus persicae (Sulzer), Thrips tabaci Lind. and Jassid, Empoasca discipiens Poali were found in low densities throughout the season.

I.Population Fluctuation of Some Piercing-Sucking Pests and the Common Natural Enemies and Relation to Weather Factors on Broad Bean Plants:

\section{A.The Population of Piercing-Sucking Pests:}

\section{Population of Aphid:}

\section{a. The Pea Aphid, Acyrthosiphon pisum:}

Data illustrated in Figures (1\& 2) showed that the population dynamics of the pea aphid, A.pisum started with attacks broad bean after three weeks of the plantation, and the population gradually increased in number and reached the first peak in early in January recorded 55.5 and 50.3 individuals/10 plants in the first and second season, respectively. After that, the population of aphid gradually decreased in number from the second week of January till the first week of February, and gradually increased again and reach the second peak in mid-March recorded 48.8 and 43.6 individuals/ 10 plants during the two seasons, respectively. The general mean population of A. pisum was higher during (2018-2019 season) recorded 32.46 ind. than the second season (2019-2020) recorded 27.40 ind. Table (1).

Statistical analysis present in table (2) showed that the maximum temperature was a non-significant negative correlation with the density of the population of $\mathrm{A}$. pisum, during the two successive seasons. However, relative humidity had a non-significant negative correlation with the mite population in the first season and a non-significant positive correlation in the second season.

\section{b. The Legume Aphid, Aphis craccivora:}

The data in figures (1\& 2) showed that the infestation of broad bean with A. craccivora was started at two months after sowing on $23^{\text {rd }}$ and $29^{\text {th }}$ December (5.3 and 7 individuals $/ 10$ plants) then it was increased sharply to reach its maximum (67.8 and 60.7 individuals /10 plants) on $24^{\text {th }}$ and $22^{\text {nd }}$ March in the first and second season, respectively. After that, the insect population fluctuated and decreased gradually to a moderate level at the end of two seasons. The general mean population of A. craccivora was higher during 2018-2019 seasons (26.72 ind.) than the second season 2019-2020 (21.68 ind.) as shown in Table (1).

As shown in table (2), the results indicated a non-significant negative correlation between the populations of aphid and mean daily maximum $(r=-0.06 \&-0.30)$, during the two seasons. In addition, a significant positive correlation was found between the insect populations and mean minimum temperature in the second season and non-significant the first season (0.70\& 0.36). Non-significant correlation between the aphid population and daily relative humidity $(\mathrm{r}=-0.3 \& 0.23)$ during the season, respectively. 


\section{c.Green Peach Aphid, Myzus persicae (Sulzer):}

As shown in Figures $(1 \& 2)$ showed that broad bean leaves infestation with $M$. persicae it has one annual peak in mid January during two seasons. The population was started after one month after sowing on $18^{\text {th }}$ and $24^{\text {th }}$ November $(3.0 \& 3.6$ individuals $/ 10$ plants) then it was increased sharply to reach its maximum (34.3 and 30.2 individuals/10 plants) in mid January in the first and second seasons. After that the aphid population fluctuated and decreased gradually to till end season in mid April.

The aforementioned results in Table (2) Clarified that, highly significant negative correlation between the insect density and maximum temperature $\left(-0.88^{* *} \&-0.77 * *\right)$ in two seasons; but non-significant negative between the aphid and both minimum temperature and relative humidity in the first season $(-0.13 \&-0.04)$, while these relation non-significant positive with aphid and the relative humidity in the second season $(0.42)$.

These results are agreement with finding by Shalaby et al, 2012 indicated that the weather factors and plant age had a significant effect on the population fluctuations of $A$. craccivora and E. discipiens. Also, the relative humidity had shown no significant effect on population fluctuations of the two insect pests during the two seasons. Also, these results are in agreement with the finding by (Mousa and Metwally, 2014, Awadalla et al. 2016, ElSarand et al. 2019 and Khodeir et al, 2020).

\section{d.The Onion Thrips, Thrips tabaci Lind:}

The population of thrips was recorded with low numbers in the two seasons. T. tabaci population it has one annul peak record (30.5\& 27.2 ind./ 10 plants) in the third week of December in the two seasons figures (1\&2). Statistical analysis of Table (2) data showed that the relationship between the thrips population and maximum temperature and relative humidity were non-significant during the two seasons.

\section{e. The jassid, Empoasca decipiens Paoli:}

E. decipiens is a polyphagous insect pest of several major crops especially bean. Both the adults and nymphs feed by puncturing the phloem vessels of the leaves. Data presenting in figures (1\&2) showed that the population of jassid was appeared on leaves of broad bean in early January and gradually increased in number and reach its peak in the midMarch record (41.8 and 36.8 ind./10 plants) in the first and second seasons, respectively. The general mean population of E. decipiens was higher during 2018-2019 seasons (20.30 ind.) than the second season 2019-2020 (17.01 ind.) Table (1).

Statistical analysis of Table (2) data revealed that the relationship between the thrips jassid population and maximum, minimum temperature, and relative humidity were non-significant during the two seasons.

These results are agreement with finding by Ammar et al., 1977 showed that the population fluctuation of $E$. decipiens was high in the warmer months, regardless of relative humidity and in the monthly sweep-net samples, was caught on 19 field crops, especially broad bean. Also, these results are agreement with finding by Mousa and Metwally, 2014, indicated that A.craccivora, and E. decipiens are considered destructive pests which invade broad bean plant causing serious damage throughout the planting stages of broad bean. A.craccivora infest seriously broad bean at the upper part of the plant during the vegetative stage. While E.decipiens greatly invade broad bean at the middle and upper part of the plant during the fruiting stage. Hashem and Abd El-Samed (2009), indicated that E. decipiens had one peak on broad bean in the third week of February and the first week of March during two seasons in Kafr El-Sheikh. 


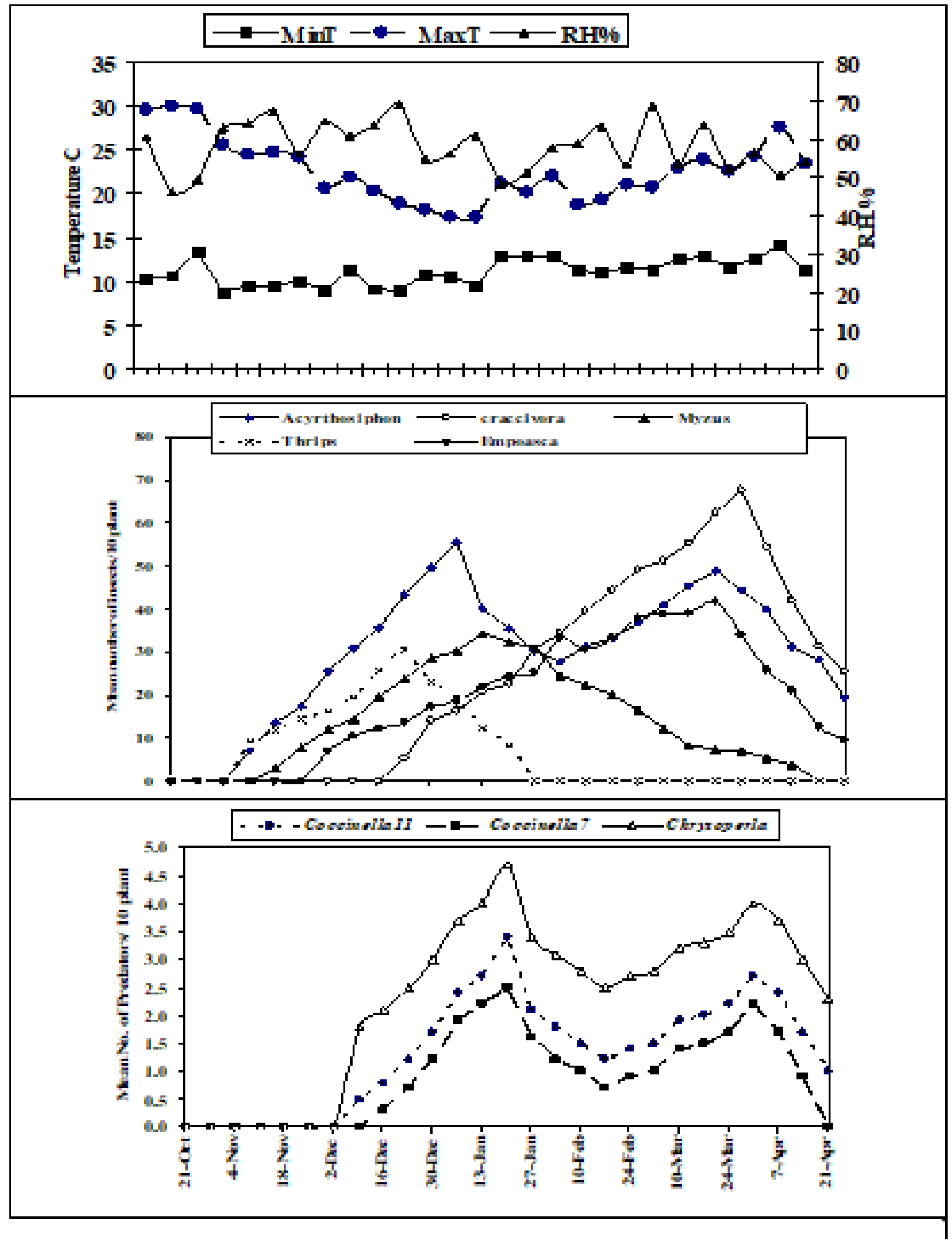

Fig.1. Population fluctuation of some piercing sucking pests and the common natural enemies and relation to weather factors on broad bean plants during season $2018 / 2019$. 


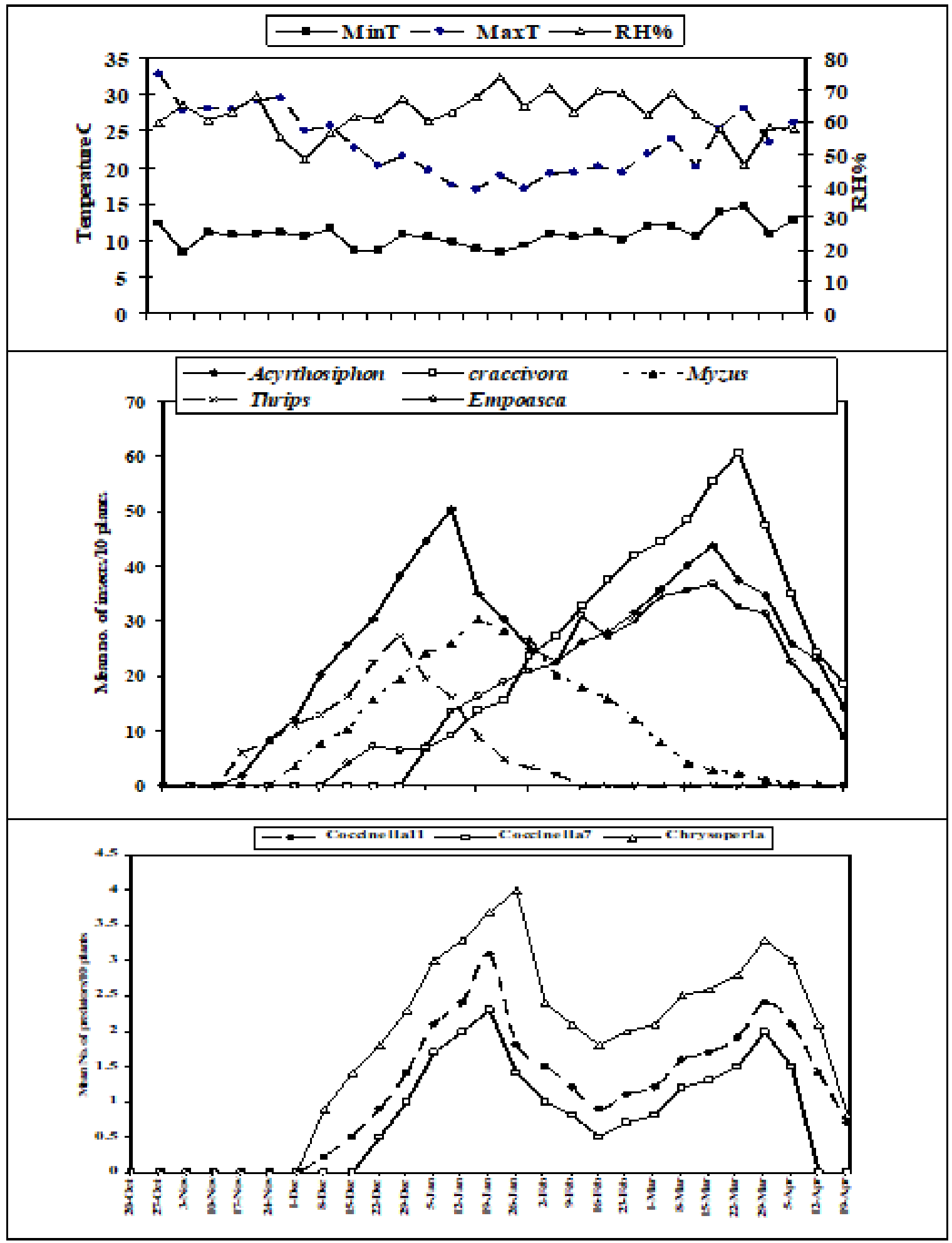

Fig.2. Population fluctuation of some piercing sucking pests and the common natural enemies and relation to weather factors on broad bean plants during season 2019/2020. 


\section{Population of Predators:}

The eleven spotted lady beetle, Coccinella undecimpunctata L., green lacewing, Chrysoperla carnea (Stephens), and seven-spotted lady beetle, Coccinella septempunctata L. are the most important predators which associated with the sucking insect pests on faba bean.

The aforementioned results in Table (1) and Figures (1\&2) Clarified that the ladybird's coccinellid predator, $C$. undecimpunctata and $C$. septempunctata started to appeared in the $2^{\text {nd }}$ week of December 2018 and gradually increased in number and reach its peak in $3^{\text {rd }}$ week in January (3.4 and 2.3 ind. $/ 10$ plants), after that the population fluctuating and decreased in number till mid-February and increased gradually increased record the second peak in late March (2.7 and 2.0 ind./10 plants), respectively. The same trend of the predator population was recorded in the second season.

Table 1:General mean number of population fluctuation of some piercing sucking pests and the common natural enemies in Ismailia Governorate during two seasons.

\begin{tabular}{|l|c|c|c|c|c|c|c|c|}
\hline \multirow{2}{*}{ Season } & \multicolumn{5}{|c|}{ piercing sucking pests } & \multicolumn{3}{c|}{ Predators } \\
\cline { 2 - 9 } & $\begin{array}{c}\text { Acyrthosiphon } \\
\text { pisum }\end{array}$ & $\begin{array}{c}\text { Aphis } \\
\text { craccivora }\end{array}$ & $\begin{array}{c}\text { Myzus } \\
\text { persicae }\end{array}$ & $\begin{array}{c}\text { Thrips } \\
\text { tabaci }\end{array}$ & $\begin{array}{c}\text { Empoasca } \\
\text { discipiens }\end{array}$ & $\begin{array}{c}\text { C. } \\
\text { undecimpunctata }\end{array}$ & $\begin{array}{c}\text { C. } \\
\text { septempunctata }\end{array}$ & $\begin{array}{c}\text { C. } \\
\text { carnea }\end{array}$ \\
\hline $\begin{array}{l}2018- \\
2019\end{array}$ & 32.46 & 26.72 & 14.55 & 7.59 & 20.30 & 1.44 & 0.98 & 2.48 \\
\hline $\begin{array}{l}2019- \\
2020\end{array}$ & 27.40 & 21.68 & 11.10 & 6.36 & 17.01 & 1.20 & 0.81 & 1.92 \\
\hline
\end{tabular}

Statistical analysis of Table (2) data revealed that the relationship between the two ladybird population and the maximum temperature and was insignificant negative, while it was insignificant negative with R.H. in the first year while in the second reason it was nonsignificant positive.

The relationship between the two ladybird's population and the three aphids and jassid populations was a positive correlation during two seasons. Whereas, this relation between the two predators and thrips was a non-significant negative correlation during the two seasons Table (2).

Table 2: the correlation coefficient between temperatures, relative humidity, piercing-sucking pests and their associated predators on faba bean plants during 2018-2019 and 20192020.

\begin{tabular}{|c|c|c|c|c|c|c|c|c|c|}
\hline \multirow[t]{2}{*}{ Season } & \multirow[b]{2}{*}{ Parameters } & \multicolumn{5}{|c|}{ Correlation coefficient values } & \multirow[b]{2}{*}{ Mini Temp } & \multirow[b]{2}{*}{ Max Temp } & \multirow[b]{2}{*}{ Mean $\mathrm{RH}$} \\
\hline & & $\begin{array}{c}\text { Acyrthosiphon } \\
\text { pisum }\end{array}$ & $\begin{array}{c}\text { Aphis } \\
\text { craccivora }\end{array}$ & $\begin{array}{l}\text { Myzus } \\
\text { persicae }\end{array}$ & $\begin{array}{l}\text { Thrips } \\
\text { tabaci }\end{array}$ & $\begin{array}{l}\text { Empoasca } \\
\text { discipiens }\end{array}$ & & & \\
\hline \multirow{6}{*}{$\begin{array}{l}2018- \\
2019\end{array}$} & C.undecimpunctata & $0.65^{*}$ & 0.60 & 0.43 & -0.34 & 0.62 & 0.44 & -0.48 & -0.35 \\
\hline & C. septempunctata & $0.65^{*}$ & 0.57 & 0.45 & -0.30 & 0.60 & 0.37 & -0.47 & -0.30 \\
\hline & C. carnea & $0.71^{*}$ & 0.63 & 0.44 & -0.32 & $0.68 *$ & 0.49 & -0.52 & -0.35 \\
\hline & Max.Temp & -0.58 & -0.06 & $-0.85^{* *}$ & -0.22 & -0.43 & - & - & - \\
\hline & Min. Temp & 0.19 & $0.70^{*}$ & -0.13 & $-0.70 *$ & 0.57 & - & - & - \\
\hline & Mean RH & -0.003 & -0.30 & -0.04 & 0.46 & -0.23 & - & - & - \\
\hline \multirow{6}{*}{$\begin{array}{l}2019- \\
2020\end{array}$} & C.undecimpunctata & 0.62 & 0.52 & 0.41 & -0.32 & 0.62 & 0.05 & -0.58 & 0.20 \\
\hline & C. septempunctata & 0.61 & 0.48 & 0.45 & -0.26 & 0.58 & 0.05 & -0.53 & 0.22 \\
\hline & C. carnea & $0.67 *$ & 0.54 & 0.50 & -0.28 & $0.67 *$ & -0.07 & $-0.66^{*}$ & 0.32 \\
\hline & Max.Temp & -0.57 & -0.30 & $-0.77 * *$ & 0.06 & -0.49 & - & - & - \\
\hline & Min. Temp & -0.06 & 0.36 & $-0.66^{*}$ & -0.43 & 0.21 & - & - & - \\
\hline & Mean RH & 0.19 & 0.23 & 0.42 & -0.16 & 0.36 & - & - & - \\
\hline
\end{tabular}

The common predators in faba bean fields were $C$. carnea, the most abundant. The numbers of predators firstly appeared in few numbers coinciding with the first appearance of the considered insect pests Figures (1\&2). The population of the predator has two peaks in the $3^{\text {rd }}$ week of January and the end of March during two seasons.

The relationship between the $C$. carnea individuals was negative with either 
maximum temperature or the relative humidity in the first season $(-0.52 \&-0.35)$, while this relation was insignificant positive with $\mathrm{RH}$. in the second season.

The relationship between $C$. carnea population and the three aphids and jassid population was a positive correlation during two seasons. Whereas, this relation between the two predators and thrips was a non-significant negative correlation during the two seasons Table (2).

These results agree with those obtained by Srikanth and Lakkundi, 1990 they found the activity of predatory coccinellids started 1 to 3 weeks after the appearance of aphids. The peak predator population more or less coincided with the peak aphid population. Highly significant positive correlations were found between weekly aphid and predator populations in the two seasons.

\section{II.Yield Losses by Aphid Infestation:}

The dimension of damage due to aphid infestation on broad bean was evaluated by comparing the yield of naturally infested plants (unsprayed) with non-infested healthy plants (sprayed) during the two seasons. Data presented in Table 3, indicated that the yield attributes due to aphid attack were differed and significantly influenced due to the level of aphid infestation in the two seasons (LSD 0.05 being 30.79 and 24.97, respectively).

The rate of reduction in seed yield was higher in 2019/20 than 2018/19, and was found 280.0 and $380.0 \mathrm{~kg}$. /fed. in the first and second seasons, respectively. Annual averages in crop reduction were $17.07 \%$ and $21.11 \%$, respectively.

Table 3: Mean seeds yield for sprayed and unsprayed treatments and percent reduction of seed yield losses during 2018/2019 and 2019/2020 seasons.

\begin{tabular}{|c|c|c|c|c|c|c|c|c|c|c|}
\hline \multirow{3}{*}{ Treatment } & \multicolumn{6}{|c|}{ Seeds yield (kg./fed.) and Reduction \% during season } & \multirow{2}{*}{\multicolumn{2}{|c|}{$\begin{array}{l}\text { Mean seeds yield } \\
\text { (kg./fed.) }\end{array}$}} & \multirow{3}{*}{$\begin{array}{l}\text { Additional } \\
\text { yield over } \\
\text { unsprayed } \\
\text { (kg. / fed.) }\end{array}$} & \multirow{3}{*}{$\begin{array}{c}\text { Avoidable } \\
\text { losses in } \\
\text { seeds } \\
\text { yield \% }\end{array}$} \\
\hline & \multicolumn{3}{|c|}{$2018 / 2019$} & \multicolumn{3}{|c|}{$2019 / 2020$} & & & & \\
\hline & Sprayed & unsprayed & $\% \mathrm{R}$ & Sprayed & unsprayed & $\% \mathrm{R}$ & Sprayed & $\begin{array}{c}\text { unspray } \\
\text { ed }\end{array}$ & & \\
\hline Mean \pm SD & $\begin{array}{l}1640.0 \\
\pm 20.4 \mathrm{a} \\
\end{array}$ & $\begin{array}{r}1360.0 \\
\pm 14.7 \mathrm{~b} \\
\end{array}$ & 17.07 & $\begin{array}{l}1800.0 \\
\pm 18.3 \mathrm{a} \\
\end{array}$ & $\begin{array}{l}1420.0 \\
\pm 9.1 \mathrm{~b} \\
\end{array}$ & 21.11 & & & & \\
\hline T-value & \multicolumn{3}{|c|}{$30.95^{* * *}$} & \multicolumn{3}{|c|}{$86.64^{* * *}$} & 1720.0 & 1390.0 & 330.0 & 19.18 \\
\hline LSD at $5 \%$ & \multicolumn{3}{|c|}{30.79} & \multicolumn{3}{|c|}{24.97} & & & & \\
\hline
\end{tabular}

The highest mean seed yield was obtained from protected than in unprotected was 1720.0 and $1390.0 \mathrm{~kg}$. / fed., respectively. The loss in seed yield in the two tested seasons 2018/19 and 2019/20 all together being (330.0 kg. /fed). The avoidable losses in seeds yield were (19.18\% per fed.) during two seasons.

The obtained results are in harmony with that detected by El-Defrawi et al. 1998 observed 82.40 to 88.30 percent yield loss due to aphid, the additional yield from protected field plot as compared to unprotected plot ranges from 0.160 to 0.799 and 0.176 to 0.773 ton /fed. In 2006/2007 and 2007/2008 respectively under different cultivars. In addition, El-Defrawi and El-Harty, 2009 found that the annual reduction in seed yield obtained due to aphid infestation in the two years was 0.414 and 0.487 ton /fed., respectively. During all together of the two years of study, the seed yield was lowest in unprotected condition.

\section{REFERENCES}

Abdel-Alim, A.A. (1994). Ecological studies on certain insects infesting cowpea plants in Minia region. El-Minia Journal of Agricultural Research and Development, 16(2): 261273.

Allam, R. O. H. (2009). Effect of certain pesticides on some insects associated with broad 
bean in Quena region, Egypt. M.Sc. Fac. Agri. Minia Univ., 153pp.

Ammar, E. D., Nahal, E. L., EI-Bolok, A. K. M., Nahal, M. M., Bolok, A. K. M., Bolok, M. ME. L. (1977). Fluctuations of population densities of Empoasca decipiens paoli and Balctutha hortensis Lindb at Giza, Egypt (Homoptera, Cicadellidace). Bulletin of the Entomological society of Egypt, 61:245-25.

Awadalla, H. S. S., EL-Kady, H.A., EL- Khyatt, E.F. and Hegab, M.A. (2016). Ecological studies on aphid species infesting different leguminous vegetable plant varieties with regard to their seasonal abundance. Mansoura Journal of Plant Protection and Pathology, 7: 733-740.

Bylund, H. (1999). Climate and the population dynamics of two insect outbreak species in the North. Ecolology. Bulletin, 47: 54-62

El-Defrawi, G.M. and El-Harty, E.F. (2009). Injury levels and yield loss model for the cowpea Aphid, Aphis craccivora koch on Vicia faba L. Egyptian Journal of Agricultural Research. 87 (2): 1-25.

El-Dfrawi, G. M. and Mokhtar, S. A. (2007). Evaluation of some faba bean (Vicia fabaL.) genotypes for resistance to cowpea aphid, Aphis craccivora Koch. Egyptian Journal of Applied Sciences. 22(6A): 294-309.

El-Defrawi, G.M. and Shalaby, F.H. (2002). Field resistance of Vicia faba breeding lines to attack by cowpea aphid, Aphis craccivora Koch in Egypt. Journal of Agricultural Science Mansoura University, 27 (9): 5701-5712.

El-Defrawi, G.M., Emam, A.K. and Shalaby, F.H. (1998) Economic injury levels and economic thresholds of Aphis craccivora Koch on faba bean in Egypt. (Homoptera: Aphididae). Annals of Agricultural Sciences Ain Shams University, Cairo, 43 (2): 289298.

El-Heneidy, A.H.; Fayed, Y.H. and Shoeb, M.A. (1991). Influence of insecticidal application on aphid populations and their natural enemies in wheat fields. The Egyptian Journal of Biological Pest control, 1(2): 79-85.

El-Sarand, E. A., Refaei, E. A. and El-Dewy, M. E. H. (2019). Population density of Empoasca Spp.; Liriomyza trifolii (Burgess) and the common natural enemies on faba bean plants in relation to sowin g dates in Kafr El-Sheik Governorate. Journal of Plant Protection and Pathology, 10 (2): 147 - 153.

Hannou, M.A. (1995). Insects, snails, diseases and weeds associated with broad bean fields in Alexandria. Egyptian Journal of Applied Science, 10(9): 351-358.

Hashem, M. S. and Abd El-Samed, A. A. (2009). Monitoring and seasonal abundance of the leaf hopper Empoasca decipiens Paoli and their associated predators on some leguminous vegetable crops. The Egyptian Journal of Biological Pest control, 19 (2) $105-114$

Khattab, M. A., Khalafalla, E. M. E. and Abou Mostafa, R. A. I. (2014). Field evaluation of certain faba bean genotypes to Aphis craccivora Koch infestation with special reference to yield. Egyptian Journal of Plant Protection Research, 2: 36-47.

Khodeir, I.A., Khattab, M.A., Rakha, O.M., Sharabash, A.S., Ueno, T. and Mousa, K.M. (2020). Population densities of pest aphids and their associated natural enemies on faba bean in Kafr EL-Sheikh, Egypt. Faculty of Agriculture, Kyushu University, Fukuoka, Japan, 65(1), 97-102.

Mahmoud, M. A., El-Khawass, K.A., Hammad, S.A. and Ali, M.I. (2017). Effect of temperature, relative humidity and natural enemies on some insect pests infesting faba bean plants at El-Monofia Governorate. Mansoura Journal of Plant Protection and Pathology, 8 (9), 447 - 451. 
Mousa, E. A. M and Metwally, S.A. (2014). Population density of the three destructive insect pests infesting broad bean (Vicia faba L.) in Kafr El Sheikh Governorate. Mansoura Journal of Plant Protection and Pathology, 5 (12): 1191 - 1199.

Nuessly, G.S.; Hentz, V; Beiriger, R. and Scully, B.T. (2004) Insects associated with faba bean, Vicia faba (Fabales: Fabaceae), in Southern Florida. Florida Entomologis, 87(2), 204-211.

SAS Institute, (2003). SAS Statistics and Graphics Guide, Release 9.1.3. SAS Institute, Cary, North. Carolina 27513, USA.

Shalaby, H. H., Mousa, E.M. and El-Gawwad, S.A. (2012). Population flactuations of some insect pests infesting broad bean plantations in relation to certain ecological factors. Journal of Plant Protection and Pathology, 3 (9): 935 - 942.

Srikanth, J. and Lakkundi, N.H. (1990). Seasonal population fluctuations of cowpea aphid Aphis craccivora Koch and its predatory coccinellids. Insect Science and its Application, 11(1):21-26.

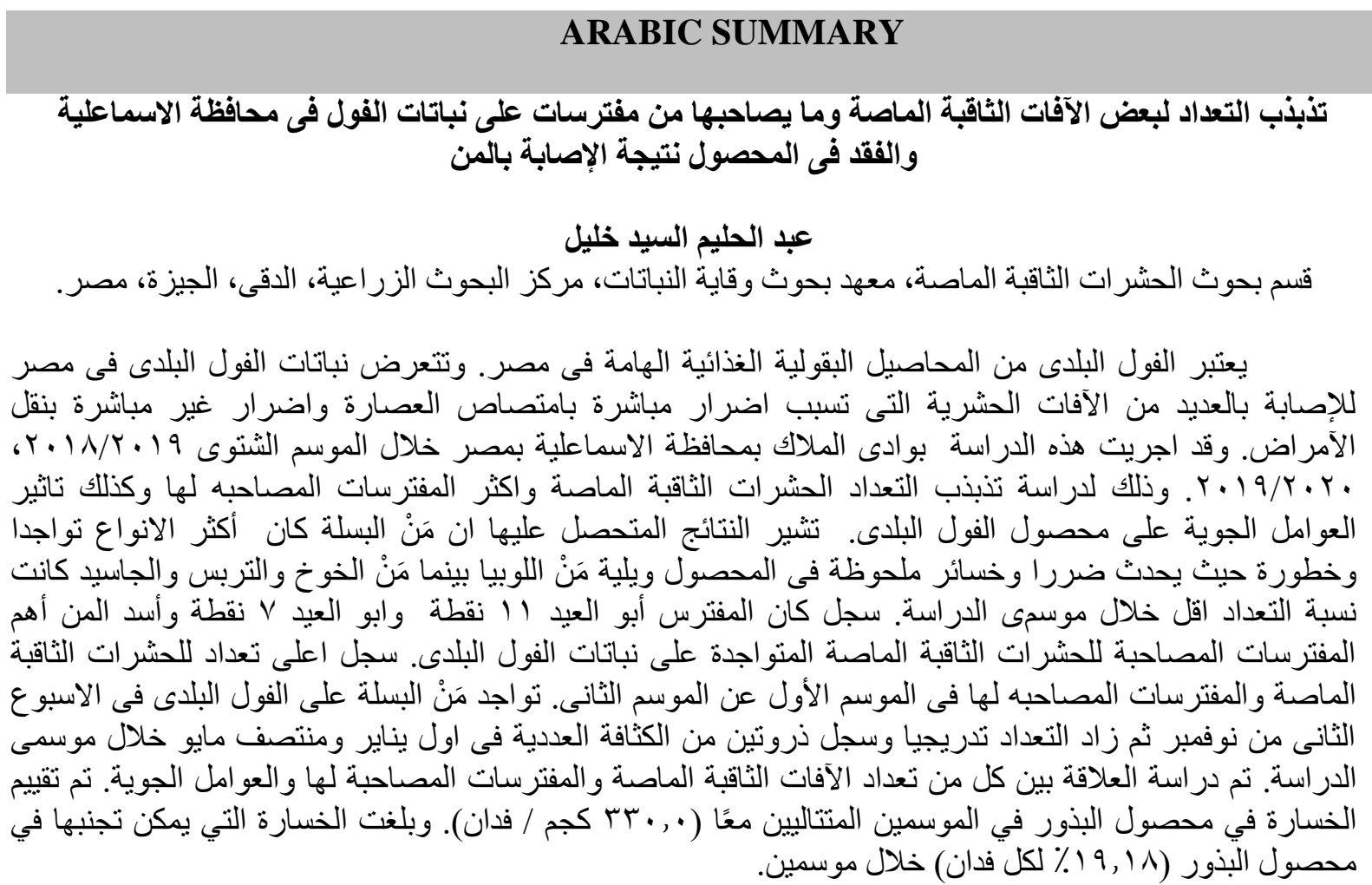

